\title{
CAN THE RENEWED INTEREST IN ULTRA-LONG-RANGE PASSENGER FLIGHTS BE SATISFIED BY THE CURRENT GENERATION OF CIVIL AIRCRAFT?
}

\author{
Glenn S. BAXTER ${ }^{1}$, Nicholas S. BARDELL ${ }^{2}$ \\ School of Engineering, RMIT, 115 Queensberry St., Carlton 3053, Victoria, Australia \\ E-mails: ${ }^{1}$ glenn.baxter@rmit.edu.au; ${ }^{2}$ nick.bardell@rmit.edu.au (corresponding author)
}

Received 5 October 2016; accepted 25 May 2017

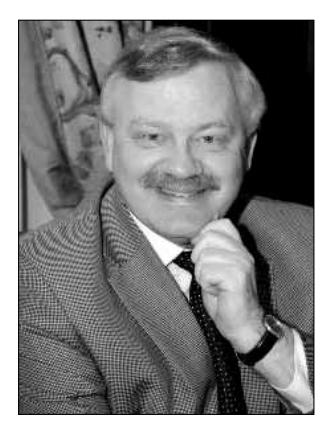

Glenn S. BAXTER, $P h D$ (Aviation)

Education: Bachelor of Aviation Studies, University of Western Sydney, Australia, 2000. Master of Aviation Studies, University of Western Sydney, Australia, 2002. PhD, School of Aviation, Griffith University, Brisbane, Australia, 2010.

Affiliations and functions: Lecturer in Aviation Management and Deputy Program Manager onshore postgraduate Aviation Programs, RMIT University, School of Engineering.

Research interests: Air cargo handling and operations, airport operations, sustainable aviation, supply chain management.

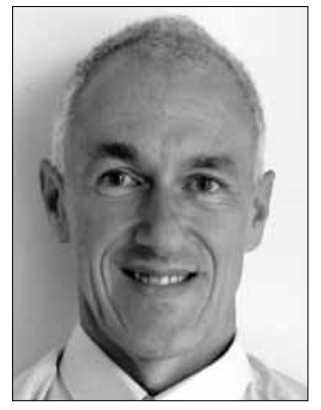

\author{
Nicholas S. BARDELL, PhD (Aeronautical Engineering) \\ Education: Bachelor of Science, The University of Salford, 43 The Crescent, Salford M5 \\ 4WT, UK, 1982. PhD, University of Southampton, University Rd, Southampton SO17 1BJ, \\ UK, 1990. \\ Affiliations and functions: FRAeS, CEng, RPEQ, Senior Lecturer in Aviation and Deputy \\ Program Manager onshore undergraduate Aviation Programs, RMIT University, School of \\ Engineering. \\ Research interests: Aircraft structures, aircraft design, air transportation, sustainable \\ aviation.
}

Abstract. A number of full service network carriers have recently stated their ambition to develop certain ultra-longrange (ULR) routes, such as Doha to Auckland, Dubai to Auckland, Dubai to Panama City, Singapore to San Francisco, Singapore to New York, all of which require a great circle distance between 7,000-9,000 nautical miles (nm) with an estimated travel time between 15 and 20 hours. This paper examines the capability of the current generation of wide-bodied passenger aircraft to satisfy this evolving strategy, and the impact, if any, on the provision of air cargo transportation. An exploratory study is presented herein based on an assessment of each aircraft type's payload-range envelope, taken from the appropriate Aircraft Airports Handling Characteristics Manual. The key findings reveal that airlines wishing to pursue this ultra-longrange strategy have a surprisingly limited choice of current-generation passenger aircraft which are capable of flying the desired mission profile without compromising significantly on passenger numbers and cargo payload.

Keywords: ultra-long range flights, payload-range envelopes, passenger transportation, current generation of civil aircraft, cargo capacity, niche markets.

\section{Introduction}

Air transportation is defined as the carriage of persons, goods, property or postal mail by air. It comprises two primary segments, the transport of passengers and the carriage of air cargo. Each segment of the industry has its own unique characteristics, yet the two are difficult to consider in isolation (Dempsey, Gesell 1997), which is why air transportation is often referred to as a "bi-polar" industry. In 2014, the world's airlines carried 3.3 billion passengers and some 50.4 million tonnes of cargo (International Civil Aviation Organization 2015). Fleet composition and route networks are two of the most important elements of an airline's business model. The world's major airlines typically structure their route networks 
according to the hub-and-spoke principle whereby they link together smaller peripheral markets via their hubs so as to optimise passenger and air cargo connectivity. Many airlines also structure their route networks on short haul, medium-haul, and long-haul services. The focus of this study is on the latter, and more specifically, the newly defined niche strategy of operating ultralong-range (ULR) services from hubs in an attempt to develop new market opportunities from a passenger and air cargo perspective. The first airline to offer a true ULR service was Singapore Airlines, which, between 2004 and 2013, operated non-stop flights between Singapore and New York using Airbus A340-500s. These flights, which covered between $8,285 \mathrm{~nm}$ on the Newark-Changi polar route, and 9,000 $\mathrm{nm}$ on the return Changi-Newark route, took approximately 18 hours, but were discontinued in 2013 due to declining passenger demand and falling profitability (Wikipedia 2016).

Recently, there has been a resurgence of interest in ultra-long-range (ULR) flights, and the following routes have received the most attention: Doha to Auckland (Qatar Airways 2016a), Dubai to Auckland (commenced in March 2016), Dubai to Panama City (anticipated start in the first quarter of 2017 or when conditions permit the introduction of the new service) (El Gazzar 2016), Singapore to San Francisco (started on June 1, 2016) (United Airlines 2016), and Singapore to New York (anticipated start in 2018) (Singapore Airlines 2015); all these require a great circle distance between 7,000-9,000 nm with an estimated travel time between 15 and 20 hours. The aim of this study is to examine the ability of the current generation of wide-bodied civil aircraft to satisfy the ambitions of airlines to service such ULR routes. In light of the growing importance of air cargo as a strategic business segment, this paper also examines the ability of current wide-bodied civil aircraft to offer a worthwhile payload capacity on ULR routes that could be used for such cargo carriage.

This paper consists of three sections. The literature review presented in Section 1 commences with a brief overview of ultra-long range (ULR) services, airline route networks, air cargo and a review of the civil aircraft payload-range envelope explaining how it quantifies aircraft performance. The research method used in the study is described in Section 2. The empirical examination of the current generation ULR capable aircraft and the Qatar Airways Doha to Auckland case study are presented in Section 3.

\section{Background}

\subsection{Ultra-long range services - key concepts}

There is no absolute definition of ultra-long-range flight distances, primarily because aircraft performance improves over time. In the 1970's, ULR was understood to mean any non-stop flight distance in excess of 5,000 $\mathrm{nm}$, which was quite a remarkable achievement for that era, as typified by the first generation of wide-bodied "jumbo" jets such as the Boeing 747 and the McDonnell-Douglas DC-10 series 40. However, nowadays it is more appropriate to define ultra-long-range (ULR) as any non-stop flight carrying an economically meaningful payload of passengers and air cargo over a distance in excess of 7,000 nm.

The emerging trend for airlines to offer ULR services fills a niche market requirement for air travellers and air cargo shippers who are increasingly demanding the shortest possible journey time from their origin to their destination. In addition, by eliminating en-route intermediate stopovers, passenger facilitation is simplified by avoiding the requirement for transit documentation, and new opportunities are created for cargo transportation, thus benefitting the economies of the states of origin and destination.

As previously noted, the proposed new ULR services are being offered by Emirates Airline, Qatar Airways, Singapore Airlines and United Airlines. These airlines follow the conventional "full service network carrier" (FSNC) business model. Thus, they are airlines that focus on providing a wide range of both pre-flight and onboard services, including different classes of service, and connecting flights via their hub(s) (Ehmer et al. 2008). These four carriers are proposing ULR services that are timed to depart from and arrive back at their major hub airport so as to optimize both passenger and air cargo connectivity. This strategy enables these airlines to optimize the available city pairs for their passengers and air cargo customers. However, more importantly, in order to operate such long range services, these airlines require aircraft with the ability to carry a favourable economic payload of both passengers and cargo over the distance to ensure profitability.

\subsection{Airline route networks: a brief overview}

Fleet routing and flight scheduling are the two most critical activities of an airline's operation, affecting its profitability, its level of service, and its competitive ability (Yan, Chen 2008). A route network is a collection of origins and destinations (O\&Ds), often called citypairs. If a single city-pair is regarded as one product of the airline, then, the larger the airline route network, the greater is its range of products. Route networks are therefore a factor in differentiating airlines (Kleymann, Seristö 2004) and the addition of extra routes, whether by inaugurating new city-pairs or by entering strategic alliances, is primarily how airlines satisfy passengers' preferences for an extended network (Oum, Yu 1998). The evolving strategy of airlines offering ULR routes appears to satisfy both new O\&D opportunities, and 
to offer passengers an extended service on routes that currently connect city-pairs but require a stopover enroute.

As the numbers of passengers increase on a route, it becomes possible for airlines to deploy larger aircraft types and/or offer a more frequent service. Furthermore, in the airline industry, there are "thin" routes, that is, routes with a small number of passengers per day, and "dense" routes, where there are substantial numbers of passengers per day. Typically, dense air routes receive a point-to-point service, whilst thin routes are combined through the use of the hub-and-spoke system (Morrison 2007). This latter practice is relevant to the present study, as the proposed ULR routes are pioneering thin routes (smaller volumes of air traffic) which are being connected to the respective airline's hub(s).

\subsection{Provision of lower deck hold capacity on combination airline passenger services}

Air cargo is now an integral part of the global economy, carrying approximately 35 per cent of world trade by value, and represents an important revenue source for the world's airlines (International Air Transport Association 2015). In the global air cargo industry, air cargo is carried by combination airlines, dedicated all-cargo carriers, and integrators such as FedEx and UPS; combination airlines form the focus of this paper.

The raison d'etre of a combination airline is to provide a priority service to passengers, whereas any remaining payload availability can then be devoted to cargo carriage. This arrangement, in which passengers are carried on the aircraft's main deck, and cargo is carried below in the lower deck "belly hold" compartments, is referred to as a combination aircraft (Dempsey, Gesell 1997). Whilst each wide-bodied civil aircraft is designed and built with a certain amount (volume) of lower deck cargo capacity, and sized to accommodate a number of industry-standard aircraft unit load devices (ULDs) such as containers or pallets, it will be shown in Section 1.4. that it may not always be feasible to use this capacity to its full extent, because the aircraft may be weight-limited or even fuel-limited, which will impose restrictions on the availability of cargo carriage (Billings et al. 2003).

\subsection{Civil aircraft performance: the payload-range envelope}

Aircraft performance refers to the capabilities and limitations of an aircraft in different phases of flight (Holloway 2008). An aircraft has a limited lift capability, whether this is dictated by takeoff performance limitations or the certified maximum takeoff weight (MTOW). This lift capability can be used to lift or carry some combination of payload and fuel, the aggregate of which is limited. The maximum distance that an aircraft can fly, given a certain amount of fuel in the tanks, is referred to as the aircraft's range. Generally, as the range increases, the payload decreases, and a weight trade-off occurs between the fuel required to operate the service and the payload which needs to be carried (Horonjeff et al. 2010).

The primary means of assessing the overall performance of a civil aircraft is from its payload-range graph, which provides an envelope showing how payload capacity varies with flight range. Full details are available from other sources (Belobaba 2016; Schmitt, Gollnick 2016; Torenbeek 1976), and only a brief description is presented here. A typical payload-range envelope is shown in Figure 1, in which the range is plotted on the horizontal axis and the payload on the vertical axis. Strict definitions of the various terminology used here are provided in Appendix A.

The vertical axis displaying the payload has a false origin that corresponds to the aircraft's Operating Empty Weight $(\mathrm{OEW})$. The horizontal line $\mathrm{AB}$ is fixed at the Maximum Zero Fuel Weight (MZFW) of the aircraft. In the region $\mathrm{AB}$, the difference between the MZFW and the OEW equals the payload capacity; since the fuel tanks are only partially filled in this region, the full payload can be transported for ranges extending to $R_{B}$ simply by increasing the fuel quantity. The gross weight of the aircraft increases along line segment $\mathrm{AB}$ but remains less than the maximum value, except at point $\mathrm{B}$, which corresponds to the maximum aircraft gross weight and maximum payload weight even though there still remains spare fuel capacity. Point $B$ also gives the maximum possible flight range $R_{B}$ whilst carrying the maximum payload, which Morrell (2011) identifies as the point of maximum efficiency.

Between points B and C, the Maximum Take Off Weight (MTOW) limits the gross weight of the aircraft, which remains constant along the line segment BC. From Point B, the range may now only be increased by exchanging fuel weight for payload weight, i.e. payload is off-loaded whilst fuel is added, thus maintaining a constant gross weight. Point $\mathrm{C}$ occurs when the fuel tanks are completely full, a limit that is set by the aircraft's fuel tank capacity.

Along the line segment $\mathrm{CD}$, further increases in range can now only be achieved by progressively reducing the payload, since no additional fuel can be accommodated. In this region, the aircraft's gross weight is lower than the maximum value. For commercial use the region $\mathrm{CD}$ is unimportant and uneconomic, which explains why $\mathrm{R}_{\mathrm{C}}$ (instead of $\mathrm{R}_{\mathrm{D}}$ ) is generally referred to as the maximum range. At Point $\mathrm{D}$, there is no payload remaining, and $\mathrm{R}_{\mathrm{D}}$ corresponds to the ferry range of the aircraft, which is its maximum possible flight range when flown empty. 


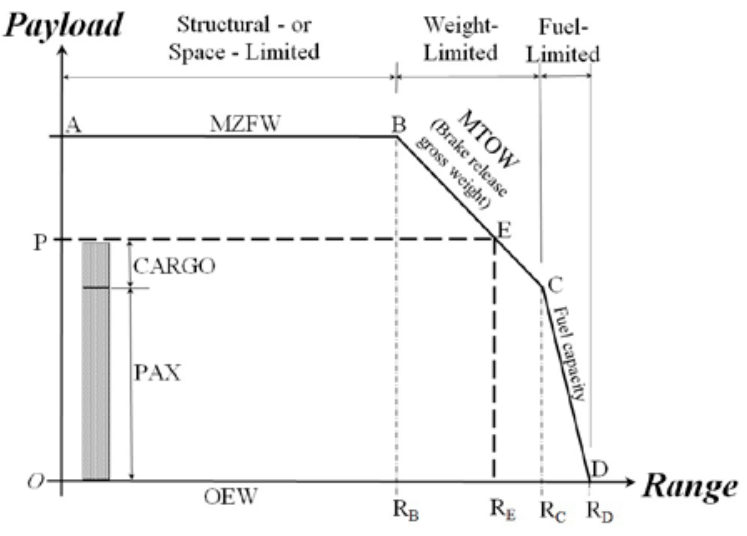

Fig. 1. Generic payload-range envelope for a typical civil aircraft

With further reference to Figure 1, for an aircraft to achieve a desired range, for example, $R_{E}$, the payload-range envelope is entered at point $\mathrm{R}_{\mathrm{E}}$, and a line is projected vertically, until it intersects the envelope at E. By projecting a horizontal line through $\mathrm{E}$ back to the payload axis at $\mathrm{P}$, the total amount of payload that can be carried by the aircraft type over the desired range can be determined. Ideally, the payload availability OP will still be sufficient for a full complement of passengers in the airline's chosen seating configuration, plus some additional cargo, as indicated schematically in Figure 1. All ULR flights will occur in the region BC, since there is no current civil aircraft designed to operate with a maximum payload for ranges $R_{B} \geq 8,000 \mathrm{~nm}$. Clearly, the aircraft offering the most promising ULR performance will be those for which Point $\mathrm{E}$ is closest to Point $\mathrm{B}$ on their specific payload-range envelope. However, in reality it may not be possible to attain the desired range without imposing considerable payload restrictions, which in turn will impact an airline's ambition to offer a particular level of service. Ultimately, all these variables are governed by the particular payload-range characteristics of a given aircraft type. Since most large full service network carriers operate a mixed fleet of aircraft types, a simple trade study based on the method described here should provide an interesting assessment of which aircraft type(s) is/are best suited to operate ULR missions.

\section{Research method}

The research undertaken in this study was broadly exploratory in nature (Dawes Farquhar 2012) and follows an inductive approach using both qualitative and quantitative methods. The goal of such an approach is to expand and build theories rather than perform statistical analysis to test a certain hypothesis (Rahim, Baksch 2003).

The qualitative and quantitative data for this study was obtained from a range of documents, such as the aircraft manufacturers' airport characteristics handling manuals, corporate brochures, industry reports, and press articles. The study therefore used secondary data analysis to investigate the title problem. The three principles of data collection suggested by Yin (2014) were followed in this study: the use of multiple sources of case evidence, creation of a database on the subject, and the establishment of a chain of evidence.

The numerical data collected for each aircraft type considered in this study was used in conjunction with the well-known payload-range envelope as the basis for determining ULR capability. (The actual process is explained in detail in Section 3.3.2.). A case study was constructed based on Qatar Airways' proposed non-stop route from Doha to Auckland, to illustrate the methodology and the capability of a particular aircraft type. As Yin (2009: 21) notes, a case study, whilst similar to an experiment, does not represent a sample, and the researcher's role is to expand and generalize theories (analytical generalization) and not to enumerate frequencies (statistical generalization).

\section{Results}

\subsection{Survey of current wide bodied civil aircraft ULR capabilities}

The aircraft types surveyed here are limited to those current wide-bodied models in service with major airlines and deemed capable of undertaking commercial flight ranges in excess of $8,000 \mathrm{~nm}$. These include the Boeing models 747, 777, and 787 (including series derivatives), and the Airbus models A330, A340, A350, and A380 (including series derivatives). Older types, such as the McDonnell-Douglas MD-11 and DC-10, and the Ilyushin IL 96-300, IL-96M, and 96T, are not included, because they do not possess sufficient range capability; in addition, both McDonnell-Douglas types ceased commercial passenger service during 2014. The Boeing 747SP, which was specifically designed for ULR flights, is nearing retirement, and only 12 aircraft remain in service at the time of writing (Boeing B747SP Website 2016) - this type is also excluded from this survey. The following assumptions are made:

- no attempt is made here to anticipate or predict any airline's operational procedures. The estimates made, and analysis performed, are based on generic information from the appropriate aircraft manufacturers' Aircraft Airports Handling Characteristics Manual, and are sufficiently accurate to support the main findings of this work;

- the payload-range data is sourced directly from the appropriate aircraft manufacturers' Aircraft Airports Handling Characteristics Manual, and assumes a standard day with zero wind and a step cruise at the relevant Mach number; 
- where different engine options are available, those giving the payload-range envelope the most favourable characteristics are used;

- the passenger numbers used here follow from the standard configuration quoted by the manufacturer in the appropriate Aircraft Airports Handling Characteristics Manual. Where more than one seating configuration is quoted, the one with the least number of passengers is conservatively quoted;

- passenger payload weight is based on the industry-standard value of $105 \mathrm{~kg}$ per person, which includes all his/her luggage. In addition, the weight of all the LD3 unit load containers required for passenger luggage must also be included. For consistency, all LD3 weight calculations are based on the Nordisk Aviation Products lightweight AKE, which is a widely used type of LD3 container, having a tare weight of $76 \mathrm{~kg}$ (Nordisk Aviation Products 2016). The required number of standard AKE LD3 containers is estimated on the widely used industry-standard assumption that, on average, each passenger has one item of luggage, and a standard AKE LD3 container holds approximately 35 bags. Thus, an aircraft with 300 enplaned passengers would require $(300 \times 1) / 35=9$ (rounded up from 8.57) AKE LD3 containers for the entire luggage, adding $9 \times 76 \mathrm{~kg}=684 \mathrm{~kg}$ to the payload;

- no account is taken of an airline's potential use of flexible routes, also known as "Flex Tracks" (Airservices Australia 2013), on a generic ULR flight mission profile.

With reference to Table 1, for each aircraft considered in this study, the make and model is quoted in Column 1, and the master series is listed in Column 2. From the relevant payload-range envelope, the ranges $R_{B}, R_{C}$ and the ferry range, $R_{D}$, are summarized in Column 3. Column 4 states the total passenger numbers from the standard seating configuration and their corresponding payload weight based on the industry-standard value of $105 \mathrm{~kg}$ per person (which includes all passenger luggage), plus the weight of the appropriate number of AKE LD3 containers required to store this luggage. The total payload availability for a prescribed ultra-longrange (ULR) flight distance of $8,000 \mathrm{~nm}$ is then determined from the appropriate Aircraft Airports Handling Characteristics Manual payload-range chart by using the construction described in Section 1.4. and illustrated in Figure 1. This value is quoted in Column 5. If the total available payload in Column 5 is less than the passenger payload in Column 4, then it is concluded the aircraft type would not be able to operate on a given $8,000 \mathrm{~nm}$ ULR route with a standard passenger complement, and comments to this effect are added in Column 6. If, on the other hand, the total available payload in Column 5 exceeds the passenger payload in Column 4, then the amount of surplus payload - which would be available for cargo provision - is quoted in Column 7.

It is noted from Table 1 that whilst achieving an ULR distance of $8,000 \mathrm{~nm}$ is possible for all the aircraft types considered here, the challenge for the majority is retaining a worthwhile payload availability over the desired range; only the Airbus A340-500 and Boeing 777-200LR demonstrate this potential. The A330-200 can just achieve the desired range carrying the standard passenger load, but there is minimal scope for cargo carriage. This analysis highlights the fact that there is a severely limited choice of aircraft types capable of servicing ULR flights with any positive commercial potential - it makes no economic sense to operate an aircraft in a niche market without a high passenger load factor and without any cargo availability. For example, the Boeing 747-8 Intercontinental could achieve the desired $8,000 \mathrm{~nm}$ range with 365 passengers and no cargo, or with just 200 passengers and 15 tonnes of cargo availability, but either scenario would likely prove too uneconomic to justify its regular use on an ULR route. In fact, the economics of "long thin routes" - routes which need long range but do not have the demand for the largest aircraft such as the Boeing 747 or Airbus A380 - work in the Airbus A340-500's and Boeing 777-200LR's favour.

It is noted that the true capability of all these aircraft is slightly better than suggested, since aircraft engaged on ULR flights would generally carry fewer passengers than normal, in order to provide a greater seat pitch than standard, thus offering a modicum of enhanced comfort for these flights which can last in excess of 15 hours. However, Table 1 serves its purpose as a good indication of aircraft capability.

Hence, prior to the service introduction of the next generation of ULR-capable civil aircraft, the default choice currently available is decidedly clear: the Boeing 777-200LR. This conclusion is perhaps not too surprising given that the majority of aircraft considered here were never optimised and intended for such extreme ultra long range operations. The fact that only 59 Boeing 777 200LRs were ever built between 2006 and 2013, of which 55 were still in airline revenue service in mid-2015 (Flight International 2015), is proof of the small numbers required to service these niche ultra-long-range markets that make up no more than a few percent of the world's airline route networks (Leeham News and Comment 2013). If the reader is wondering why the A340500 is not a credible contender in this market-space, it is because by mid-2015 there were only 8 A340-500's in service worldwide, and all the major airlines currently operating this type are in the process of accelerating its retirement (Flight International 2015). 
Table 1. Key performance measures for current wide bodied aircraft capable of ULR flights, including any payload availability to carry lower deck cargo. (See Section 3. 3. 2. for a sample investigation) (source: data derived from Boeing Commercial Airplanes 2009, 2011, 2012, 2015; Airbus SAS 2014, 2015a, 2015b, 2015c).

\begin{tabular}{|c|c|c|c|c|c|c|}
\hline 1 & 2 & 3 & 4 & 5 & 6 & 7 \\
\hline $\begin{array}{c}\text { Aircraft Make } \\
\text { and } \\
\text { Model } \\
\end{array}$ & $\begin{array}{c}\text { Master } \\
\text { Series }\end{array}$ & $\begin{array}{l}\mathrm{R}_{\mathrm{B}} \\
\mathrm{R}_{\mathrm{C}} \\
\mathrm{R}_{\mathrm{D}} \\
\end{array}$ & $\begin{array}{c}\text { Standard enplaned } \\
\text { PAX }{ }^{1} \\
\text { and PAX Weight }^{2}\end{array}$ & $\begin{array}{c}\text { Total payload } \\
\text { availability at } \\
\mathrm{R}_{\mathrm{E}}=8,000 \mathrm{~nm}^{3} \\
\end{array}$ & Comments & $\begin{array}{c}\text { Surplus payload } \\
\text { availability at } \\
\mathrm{R}_{\mathrm{E}}=8,000 \mathrm{~nm} \\
\end{array}$ \\
\hline Boeing 747 & $-400 \mathrm{ER}$ & $\begin{array}{l}6,200 \mathrm{~nm} \\
8,000 \mathrm{~nm} \\
9,100 \mathrm{~nm}\end{array}$ & $\begin{array}{l}416 \text { PAX } \\
45,000 \mathrm{~kg}\end{array}$ & $36,000 \mathrm{~kg}$ & $\begin{array}{l}\text { 4-engines. Cannot } \\
\text { carry standard PAX } \\
\text { at } 8,000 \mathrm{~nm}\end{array}$ & NIL \\
\hline Boeing 747 & -8 & $\begin{array}{l}5,900 \mathrm{~nm} \\
8,000 \mathrm{~nm} \\
9,000 \mathrm{~nm} \\
\end{array}$ & $\begin{array}{l}515 \mathrm{PAX} \\
57,000 \mathrm{~kg}\end{array}$ & $41,000 \mathrm{~kg}$ & $\begin{array}{l}\text { 4-engines. Cannot } \\
\text { carry standard PAX } \\
\text { at } 8,000 \mathrm{~nm}\end{array}$ & NIL \\
\hline Boeing 777 & $\begin{array}{l}-200 \\
\text { HGW }\end{array}$ & $\begin{array}{l}5,750 \mathrm{~nm} \\
8,600 \mathrm{~nm} \\
9,600 \mathrm{~nm}\end{array}$ & $\begin{array}{l}305 \text { PAX } \\
34,000 \mathrm{~kg}\end{array}$ & $32,000 \mathrm{~kg}$ & $\begin{array}{l}\text { 2-engines. Cannot } \\
\text { carry standard PAX } \\
\text { at } 8,000 \mathrm{~nm}\end{array}$ & NIL \\
\hline Boeing 777 & $-300 \mathrm{ER}$ & $\begin{array}{l}5,600 \mathrm{~nm} \\
7,800 \mathrm{~nm} \\
8,500 \mathrm{~nm}\end{array}$ & $\begin{array}{l}339 \text { PAX } \\
37,000 \mathrm{~kg}\end{array}$ & $14,000 \mathrm{~kg}$ & $\begin{array}{l}\text { 2-engines. Cannot } \\
\text { carry standard PAX } \\
\text { at } 8,000 \mathrm{~nm}\end{array}$ & NIL \\
\hline Boeing 777 & $-200 L R$ & $\begin{array}{l}7,500 \mathrm{~nm} \\
8,100 \mathrm{~nm} \\
9,500 \mathrm{~nm}\end{array}$ & $\begin{array}{l}279 \text { PAX } \\
31,000 \mathrm{~kg}\end{array}$ & $45,000 \mathrm{~kg}$ & $\begin{array}{l}\text { 2-engines. Standard } \\
\text { PAX plus extra } \\
\text { capacity for cargo }\end{array}$ & $14,000 \mathrm{~kg}$ \\
\hline Boeing 787 & -8 & $\begin{array}{l}, 500 \mathrm{~nm} \\
9,500 \mathrm{~nm} \\
10,000 \mathrm{~nm}\end{array}$ & $\begin{array}{l}242 \mathrm{PAX} \\
27,000 \mathrm{~kg}\end{array}$ & $21,000 \mathrm{~kg}$ & $\begin{array}{l}\text { 2-engines. Cannot } \\
\text { carry standard PAX } \\
\text { at } 8,000 \mathrm{~nm}\end{array}$ & NIL \\
\hline Boeing 787 & -9 & $\begin{array}{l}5,250 \mathrm{~nm} \\
8,250 \mathrm{~nm} \\
9,400 \mathrm{~nm}\end{array}$ & $\begin{array}{l}290 \mathrm{PAX} \\
32,000 \mathrm{~kg}\end{array}$ & $27,000 \mathrm{~kg}$ & $\begin{array}{l}\text { 2-engines. Cannot } \\
\text { carry standard PAX } \\
\text { at } 8,000 \mathrm{~nm}\end{array}$ & NIL \\
\hline $\begin{array}{l}\text { Airbus } \\
330\end{array}$ & -200 & $\begin{array}{l}4,250 \mathrm{~nm} \\
9,150 \mathrm{~nm} \\
9,250 \mathrm{~nm}\end{array}$ & $\begin{array}{l}246 \text { PAX } \\
27,000 \mathrm{~kg}\end{array}$ & $28,000 \mathrm{~kg}$ & $\begin{array}{l}\text { 2-engines. Standard } \\
\text { PAX plus minimal } \\
\text { capacity for cargo }\end{array}$ & $1,000 \mathrm{~kg}$ \\
\hline $\begin{array}{l}\text { Airbus } \\
340\end{array}$ & -500 & $\begin{array}{l}7,100 \mathrm{~nm} \\
9,100 \mathrm{~nm} \\
9,800 \mathrm{~nm}\end{array}$ & $\begin{array}{l}313 \mathrm{PAX} \\
34,000 \mathrm{~kg}\end{array}$ & $40,000 \mathrm{~kg}$ & $\begin{array}{l}\text { 4-engines. Standard } \\
\text { PAX plus extra } \\
\text { capacity for cargo }\end{array}$ & $6,000 \mathrm{~kg}$ \\
\hline $\begin{array}{l}\text { Airbus } \\
340\end{array}$ & -600 & $\begin{array}{l}5,600 \mathrm{~nm} \\
7,800 \mathrm{~nm} \\
8,800 \mathrm{~nm}\end{array}$ & $\begin{array}{l}380 \text { PAX } \\
41,000 \mathrm{~kg}\end{array}$ & $25,000 \mathrm{~kg}$ & $\begin{array}{l}\text { 4-engines. Cannot } \\
\text { carry standard PAX } \\
\text { at } 8,000 \mathrm{~nm}\end{array}$ & NIL \\
\hline $\begin{array}{l}\text { Airbus } \\
350\end{array}$ & -900 & $\begin{array}{l}5,300 \mathrm{~nm} \\
9,400 \mathrm{~nm} \\
10,100 \mathrm{~nm}\end{array}$ & $\begin{array}{l}315 \text { PAX } \\
35,000 \mathrm{~kg}\end{array}$ & $32,000 \mathrm{~kg}$ & $\begin{array}{l}\text { 2-engines. Cannot } \\
\text { carry standard PAX } \\
\text { at } 8,000 \mathrm{~nm}\end{array}$ & NIL \\
\hline $\begin{array}{l}\text { Airbus } \\
380\end{array}$ & -800 & $\begin{array}{l}6,500 \mathrm{~nm} \\
8,800 \mathrm{~nm} \\
9,500 \mathrm{~nm}\end{array}$ & $\begin{array}{l}555 \text { PAX } \\
60,000 \mathrm{~kg}\end{array}$ & $52,000 \mathrm{~kg}$ & $\begin{array}{l}\text { 4-engines. Cannot } \\
\text { carry standard PAX } \\
\text { at } 8,000 \mathrm{~nm}\end{array}$ & NIL \\
\hline
\end{tabular}

Note: all passenger (PAX) weights and payload availability weights have been rounded to the nearest $1,000 \mathrm{~kg}$.

1. The passenger numbers used here follow from the standard configuration quoted by the manufacturer in the Aircraft Airports Handling Characteristics Manual. Where more than one seating configuration is quoted, the one with the least number of passengers is conservatively quoted.

2. Passenger weight is based on the industry-standard value of $105 \mathrm{~kg}$ per person (which includes all his/her luggage), plus the tare weight $(76 \mathrm{~kg})$ of the appropriate number of AKE LD3 containers required to store all the booked passenger luggage.

3. Where different engine options are available, those giving the payload-range envelope the most favourable characteristics are used.

\subsection{The near-term future for wide-bodied civil passenger aircraft}

New twin-engined aircraft currently under development from Boeing and Airbus include the 777-8 and 777-9 from the former, and the A350-900ULR and A350-1000 from the latter. All these types offer spacious twin-aisle accommodation for over 300 passengers, highly efficient wings and engines, and the latest fly-by-wire and glass cockpit technologies. Assuming the United States 14 CFR Part 25 and the European Aviation Safety Agency (EASA) CS-25 type certification programmes proceed smoothly, entry into service for all these types is predicted somewhere between 2017 and 2021, just in time to consolidate 
Table 2. Future orders for new ULR-capable aircraft

\begin{tabular}{lll}
\hline \multicolumn{1}{c}{ Airline } & \multicolumn{1}{c}{ Aircraft Type } & \multicolumn{1}{c}{$\begin{array}{c}\text { Current Orders } \\
\text { (June 2016) }\end{array}$} \\
\hline Emirates Airline & Boeing 777-8 & 35 (Boeing Commercial Airplanes 2014) \\
\hline Etihad Airways & Boeing 777-8 & 8 (Flynn 2015) \\
\hline Qatar Airways & Boeing 777-8 & 10 (Kovessy 2015) \\
\hline Singapore Airlines & Airbus A350-900ULR & 7 (Launch Customer) (Lecompte-Boinet 2015) \\
\hline
\end{tabular}

current ultra-long-range (ULR) routes and perhaps develop new ones.

Whilst exact payload-range envelopes for these new aircraft types are currently unavailable in the public domain, it is nonetheless clear that the new Boeing 777-8 and Airbus A350-900ULR aircraft will offer a genuine ultra-long-range (ULR) capability that exceeds even that of the Boeing 777-200LR. It is of interest to note that in a bid to improve marketability and sales in this limited ULR niche market, Airbus has designed the A350900ULR long range version in such a manner that operators can easily reconfigure it to the standard long-haul A350-900 specification, should they require it. Table 2 provides a summary of the future orders of all types that have been placed at the time of writing. Although it is clear that a small number of full service network carriers intend to pursue and perhaps dominate this ultra-longrange sector, it is also evident from the relatively small number of dedicated aircraft on order that such routes will continue to remain a thin niche market.

\subsection{Qatar Airways Doha to Auckland ULR Flight Case Study.}

\subsubsection{Qatar Airways: a brief overview}

Qatar Airways, the national carrier of the State of Qatar, is one of the world's fastest growing airlines. Established in 1993, and re-launched in 1997, Qatar Airways operates a modern, mixed fleet of both narrow and wide-bodied passenger jets, with 179 aircraft in total. The airline operates both Airbus and Boeing aircraft, with 8 different types from the former, and 3 different types from the latter. The entire fleet services more than 150 key business and leisure destinations across six continents. Qatar Airways has been the recipient of many accolades and awards, including Airline of the Year, Best Business Class Airline Seat and Best Airline in the Middle East (Qatar Airways 2016b).

Qatar Airways' business model is highly dependent on 5th and 6th freedom traffic rights that enable it to service the Australasian, Asian, South American and European markets; relatively little traffic through Doha is of the origin-destination (OD) type. By pioneering ULR flights, Qatar Airways would not only improve their OD market share but also increase Gulf airline capacity.
Qatar Airways is a member of the oneworld global airline alliance, consisting of airberlin, American Airlines, British Airways, Cathay Pacific, Finnair, Iberia, Japan Airlines, LATAM, Malaysia Airlines, Qantas, Royal Jordanian, S7 Airlines, Sri Lankan Airlines and TAM Airlines. This enables the airline's passengers to benefit from services to around 1,016 destinations in 161 countries, with the alliance members operating 13,814 daily departures (oneworld 2016).

\subsubsection{Qatar Airways proposed Doha to Auckland ULR} Service - aircraft performance

Qatar Airways has 9 Boeing 777-200LR aircraft in its current fleet (Qatar Airways 2016b). These aircraft are operated on a variety of long-haul routes in which they are configured with only two cabin classes, consisting of 42 (J) Business Class seats and 217 (Y) Economy Class seats. Qatar Airways has stated its intention to use its existing Boeing 777-200LR aircraft for its proposed Doha-Auckland ULR service, and hence, for the purposes of this case study, the aircraft is assumed to retain the standard long-haul seating configuration. The following sample analysis also showcases all the steps involved in determining the various payload-range investigations shown in Table 1.

The passenger payload is calculated as follows:

Total PAX: $42+217=259$.

Passenger weight (including all luggage) at $105 \mathrm{~kg}$ per person is: $259 \times 105=27,195 \mathrm{~kg}$.

The AKE (LD3) containers for baggage hold approximately 35 bags each. Assuming that each passenger has 1 item of luggage on average, then the number of containers required is $(259 \times 1) / 35=8$ (rounded up from 7.4). In this instance, each AKE container weighs $82 \mathrm{~kg}^{1}$ (Qatar Airways Cargo 2016), so the additional container weight is $8 \times 82 \mathrm{~kg}=656 \mathrm{~kg}$.

Hence, the total passenger payload amounts to $27,195 \mathrm{~kg}+656 \mathrm{~kg}=27,851 \mathrm{~kg}$, which, allowing for minor variations, is conservatively rounded up to 30 tonnes.

\footnotetext{
1 The tare weight of aircraft unit load devices can vary slightly, for example, Nordisk Aviation Products lightweight AKE has a tare weight of $76 \mathrm{~kg}$ (Nordisk 2016), whilst each AKE used by Qatar Airways weighs $82 \mathrm{~kg}$.
} 


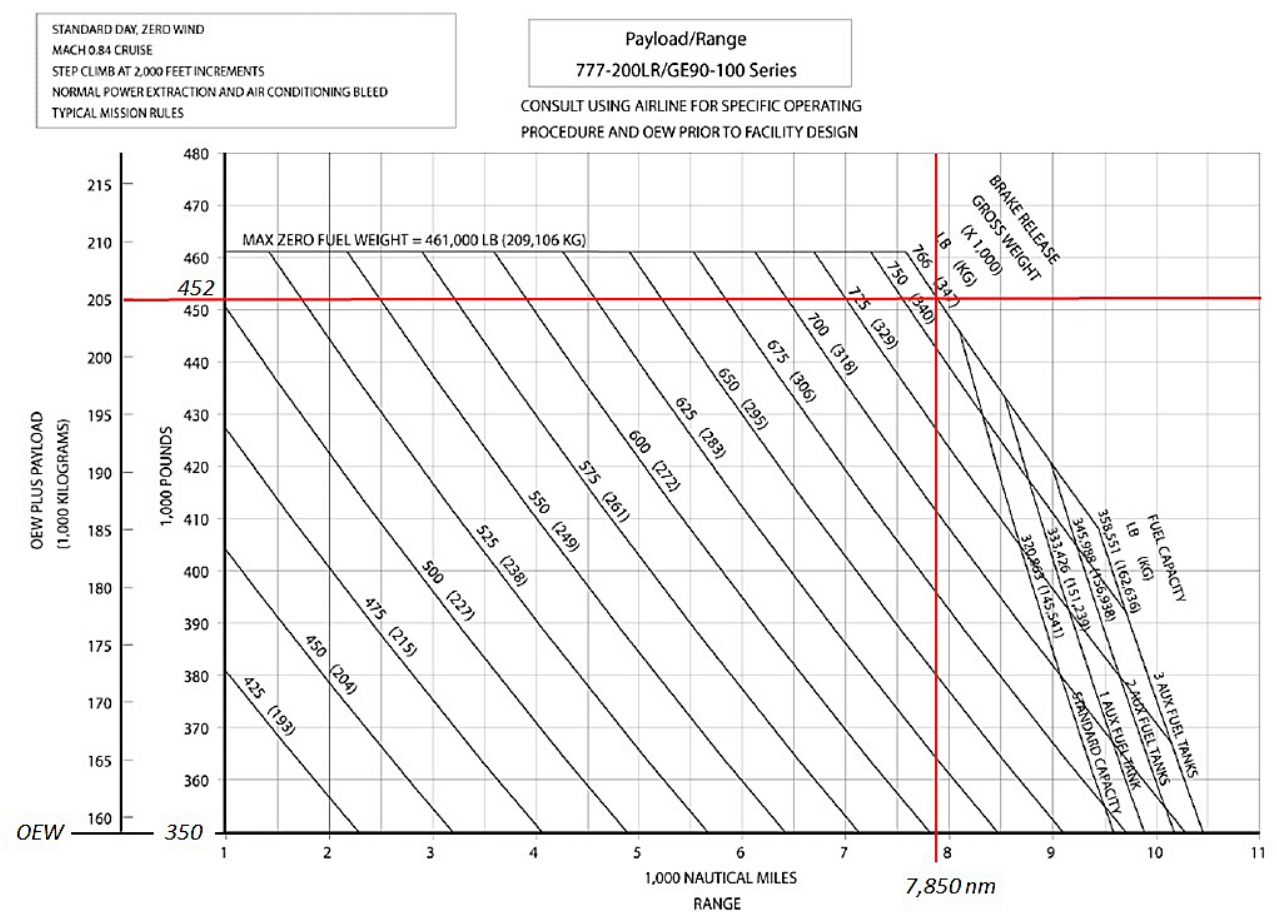

Fig. 2. Payload-range envelope for a Boeing 777-200LR (Boeing Commercial Airplanes 2009). Permission obtained from Boeing to reproduce this figure - copyright (๑ 2009. The Boeing Company. All rights reserved

The proposed Qatar Airways non-stop route from Doha (IATA Airport Code: DOH) to Auckland (IATA Airport Code: AKL) covers a great circle distance of 7,850 nm (Great Circle Mapper 2016). With reference to Figure 2, which shows the aircraft manufacturers' payload-range envelope for the Boeing 777-200LR, it is evident that the total payload availability over such a distance is approximately 46 tonnes $(452,000 \mathrm{lb}-350,000$ $\mathrm{lb}=102,000 \mathrm{lb}$ or $46,250 \mathrm{~kg}$ ). Hence, in round figures, in addition to the passenger payload of 30 tonnes, there is a surplus payload of 16 tonnes (46 tonnes - 30 tonnes) available for cargo carriage. The aircraft lower deck has a standard cargo configuration of $32 \mathrm{LD} 3$ containers (or equivalent) plus $17 \mathrm{~m}^{3}$ of bulk cargo (Boeing Commercial Airplanes 2009). So, with 8 LD3 containers reserved for passenger baggage, the lower deck design of this particular aircraft still affords more than sufficient volumetric capacity for 16 tonnes of cargo transport.

It is noted from Figure 2 that the aircraft is weight-limited, as expected, with a MTOW equal to 347 tonnes. It is also noted that the standard fuel capacity of $145,540 \mathrm{~kg}$ is sufficient for the proposed mission and there is no need to take advantage of the provision for up to three optional fuel tanks that may be added in the aft cargo area. The three sets of extension lines shown in Figure 2 for 1, 2 or 3 auxiliary fuel tanks show the sort of modest range increases that are possible.
3.3.3. Qatar Airways proposed Doha to Auckland ULR Service - airport availability

Hamad International Airport serves Doha, the capital city of Qatar, and has two main runways at sea-level $(11 \mathrm{~m})$, the Eastern Runway (16L/34R) of a length of $4,850 \mathrm{~m}$ and the Western Runway (16R/34L) of a length of 4,250 m (Hamad International Airport 2014). In contrast, Auckland International Airport has a single runway $(05 \mathrm{R} / 23 \mathrm{~L})$ at sea-level $(7 \mathrm{~m})$, and of $3,635 \mathrm{~m}$ length (Auckland International Airport 2013). For this city-pair, the Auckland International Airport runway is critical when determining the take-off runway length requirements; for the Boeing 777-200LR, landing distances are comfortably enveloped by take-off distances, and hot-day take-off distances are more critical than those required for a standard day. Assuming the GE90115B engine option applies to Qatar Airways' Boeing 777-200LR, then, from Figure 3, it can be seen that at MTOW this aircraft type would require a runway length marginally less than 3,000 m. (Note: the Federal Aviation Regulation (FAR) standard day temperature at sea-level is $15^{\circ} \mathrm{C}$. Hence the runway length chart corresponding to a standard day with $+15^{\circ} \mathrm{C}$ has been chosen to represent a hot summer's day in New Zealand). It is concluded that the runway at Auckland International Airport is quite sufficient to support the proposed ULR mission. 


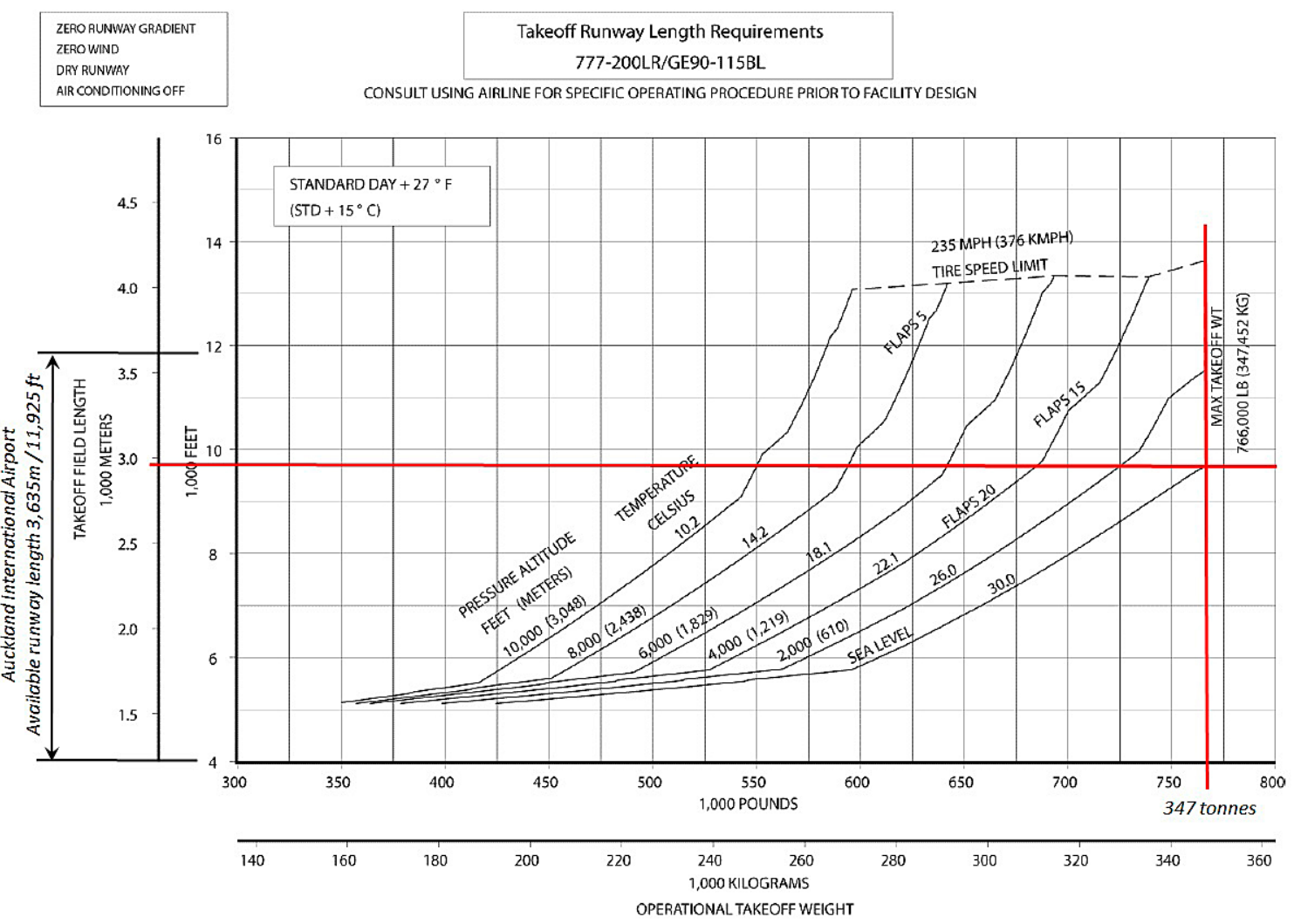

Fig. 3. F.A.R. Takeoff Runway Length Requirements - standard day with $+15^{\circ} \mathrm{C}$ : model $777-200 \mathrm{LR}$ (GE90-115B Engines) (Boeing Commercial Airplanes 2009). Permission obtained from Boeing to reproduce this figure - copyright (C 2009. The Boeing Company. All rights reserved

\subsubsection{Qatar Airways proposed Doha to Auckland ULR Service - economic and cultural benefits}

It is important to note that prior to an airline commencing international services to another country, the government must first negotiate a treaty level agreement with the destination country's government. These treaties are known as bilateral air services agreements (ASAs) (Department of Infrastructure and Regional Development 2014; Milde 2008). In September 2015, New Zealand's Minister of Trade signed an "open skies" air services agreement (ASA) with Qatar which provided Qatar Airways with the opportunity to serve New Zealand (Civil Aviation Authority, Qatar 2016). Following the signing of the ASA, on 9 March 2016, Qatar Airways formally announced the commencement of a daily nonstop ULR flight from Doha, the airline's hub, to Auckland, New Zealand - this will be the longest non-stop air route in the world (Qatar Airways 2016a). See Figure 4 for a typical great circle flight path. For Qatar Airways, the addition of the new ULR service to Auckland increases the number of possible city pair linkages. Mathematically, if an airline has $n$ spokes emanating from one hub, then an airline can provide through-connecting services up to a maximum of $n(n-1) / 2$ city pairs. The addition of one extra route increases the total number of possible O\&Ds to $n(n+1) / 2$ (Hanlon 2007).
The Middle East is home to three of the world's major airlines - Emirates Airline, Etihad Airways and Qatar Airways, all of which have rapidly developed extensive networks that link peripheral cities in Asia/Pacific, Europe, Africa, and North and South America via their respective hubs, thereby creating connectivity for both passengers and cargo between these regions/cities. However, each of these three airlines has defined and implemented quite different strategies to serve the Middle East to New Zealand market.

Emirates Airline commenced services to New Zealand, via an intermediate stopover, with a double-daily Auckland service, in August 2003, adding a third daily Auckland service several months later, and then subsequently adding a daily Christchurch service in 2004 . Since 2009, the airline has progressively up-graded its Auckland services through the introduction of several Airbus A380-800 aircraft, which presently fly from New Zealand via Sydney, Melbourne, and Brisbane respectively to Dubai and beyond, and vice versa. Shortly before the announcement of Qatar Airways' decision to operate an ULR non-stop service from Doha to Auckland, Emirates Airline announced its own new ULR non-stop service from Dubai to Auckland, which commenced on March 1, 2016 (Emirates Airline 2016). In contrast, Etihad Airways does not operate services to New Zealand 
in its own right preferring to transfer passengers and cargo to Air New Zealand on a code share basis (Etihad Airways 2016).

The key benefit of the new ULR flights to Auckland (for both Emirates Airline and Qatar Airways) is the reduction in journey time to and from New Zealand by around $3 \frac{1}{2}$ hours (Bradley 2016), as there is no longer the necessity to make a stopover in Australia (or another intermediate point). This is beneficial to time-poor passengers and to air cargo shippers; in the latter case, the reduced journey time can help sustain the product quality of high-value perishable air cargo exported from New Zealand, such as fresh fish and chilled meat.

In addition, opportunities will exist for improved cultural and tourism linkages as well as the opening of possible new export markets, for example, between New Zealand and Qatar. In signing the air services agreement with Qatar, New Zealand's Minister for Trade noted that he hoped Doha would be a gateway connecting New Zealand with the broader Middle East, Europe, and Africa (Kovessy 2016).

\subsubsection{Qatar Airways proposed Doha to Auckland ULR Service - ETOPS and ultra-long-range flights}

The ability of an airline to conduct ultra-long-range flights using twin engine passenger aircraft will be dictated by its ETOPS record, and the capability of the aircraft it intends to use. ETOPS (Extended-range Twin-engine Operational Performance Standards) is the acronym for an International Civil Aviation Organization (ICAO) and United States Federal Aviation Administration (FAA) rule permitting modern twin-engine commercial transport aircraft such as the Boeing 777 and 787, and the Airbus A330 and A350 to fly long distance routes, often over water or across deserts, which were previously off-limits to twin engine aircraft (Asselin 1997).

In order to secure ETOPS approval, a two stage process is required. For a given aircraft, "ETOPS type approval" must first be obtained from the regulatory authority in the state of design during the type certification process to ensure that the combination of airframe and engine can satisfy the ETOPS requirements. If, for example, an aircraft is rated for ETOPS-120, it means that it must be capable of flying with a full load and with only one engine operative for 120 minutes ( 2 hours). On December 12, 2011, Boeing announced it had received ETOPS type-design approval from the U.S. Federal Aviation Administration (FAA) for up to 330-minute extended operations ( $5 \frac{1}{2}$ hours) for its entire 777 fleet (Thomas 2011).

Secondly, ETOPS operational certification must be obtained by an operator who wishes to conduct ETOPS flights by satisfying their own country's aviation regulators, ensuring that they are capable of conducting such

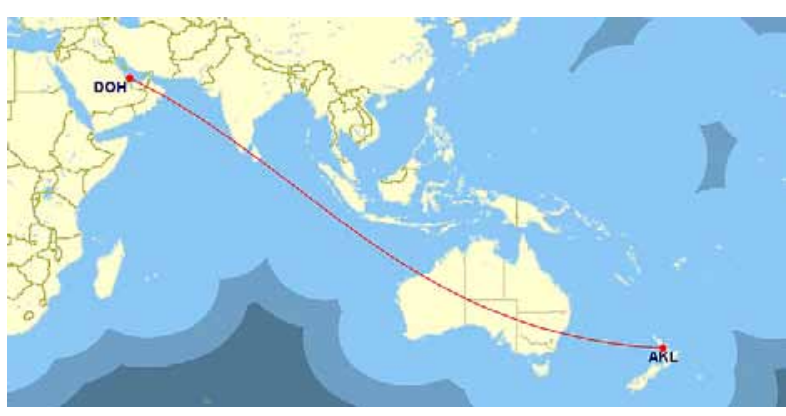

Fig. 4. The proposed Qatar Airways non-stop route from Doha to Auckland. Distance: 7,850 nm $(14,540 \mathrm{~km})$. Legend: $\mathrm{AKL}=$ Auckland; $\mathrm{DOH}=$ Doha.

(Scalloped regions with light shading represent the extent of Boeing 777-200LR 120 minutes ETOPS; scalloped regions with dark shading represent the extent of Boeing 777-200LR 180 minutes ETOPS).

Source: Great Circle Mapper http://www.gcmap.com/ Maps generated by the Great Circle Mapper - copyright (c) Karl L. Swartz.

flights. An airline that can demonstrate it has extensive experience operating long haul flights may be awarded ETOPS operational approval immediately; others may need to demonstrate capability through a staged sequence of proving flights. To fly the ULR route from Doha to Auckland, as evidenced by Figure 4, Qatar Airways would have to prove to its home regulator - the Civil Aviation Authority, Qatar - that it had sufficient operational experience with 120 (or possibly 180) minute ETOPS - a simple matter given the number of long-haul flights it already operates with the Boeing 777-200LR.

\section{Conclusions}

This study has examined the recent strategy of several major full service network carriers (FSNCs) to operate new ultra-long range (ULR) services from their hubs with flight distances in excess of 7,000 nm and flight durations in excess of 15 hours. Initially, the overall performance of all wide-bodied civil aircraft currently in service and capable of achieving a non-stop flight range of $8,000 \mathrm{~nm}$ was assessed and tabulated. The study found that airlines wishing to pursue this ultra-long-range strategy currently have a surprisingly limited choice of passenger aircraft which are capable of flying the desired mission profile without compromising significantly on passenger numbers and cargo payload. This conclusion hence answers the title question: "Can the renewed interest in ultra-long-range passenger flights be satisfied by the current generation of civil aircraft?", in the negative. It is clear there is only one current aircraft model and type, the Boeing 777-200LR, which offers a convenient blend of passenger numbers and cargo payload combined with true ULR performance. It is no coincidence, therefore, to note that the airlines currently considering such ULR flights all have a number of Boeing 
777-200LR aircraft models in their existing fleets and have stated their intentions to use them for such operations. For those airlines who have aspirations to enter the ULR niche market, but who currently have no Boeing 777-200LR's in their fleet, their options are somewhat limited: either acquire Boeing 777-200LRs from existing operators or wait until the next generation of wide-bodied aircraft become available as described in Section 4.2. A subsequent case study was then presented, which examined in some detail the Qatar Airways' proposed route between Doha and Auckland, which will be the longest scheduled non-stop passenger flight in the world covering a range of 7,850 $\mathrm{nm}$. The analysis revealed that despite the extremely long distance, by operating Boeing 777-200LR's in their current passenger configuration, Qatar Airways will retain the ability to carry an economically significant payload of both passengers and air cargo. The latter availability will be very important given the significance of high-value perishable export goods from New Zealand like fresh fish, meat, and dairy produce, and its critical time-to-market.

This work has addressed some of the key technical issues associated with the recent resurgence of interest in ULR flights in what is arguably an emergent area of aviation research. Further study is recommended to assess the potential and viability of operating such ULR routes with the next generation of long-range widebody twin-engine civil aircraft currently under development (e.g., the Boeing 777-8 and/or the Airbus A350900ULR), paying particular attention to the governing economics of these "thin" routes, the level of anticipated passenger demand, and the potential to offer a true combination service that includes cargo carriage.

\section{Acknowledgements}

The authors would like to acknowledge the kind permission of Boeing to reproduce Figures 2 and 3 herein from diagrams taken from Boeing Commercial Airplanes, (2009). 777-200LR/ 300ER/ Freighter Airplane Characteristics for Airport Planning, Document D6583292, Rev E, May 2015.

\section{References}

Airbus SAS. 2014. A330 aircraft characteristics airport and maintenance planning. Issue Jan 01/93, Rev Oct 01/15 [online], [cited 5 February 2016]. Available from Internet: http://www.airbus.com/fileadmin/media_gallery/files/ tech_data/AC/Airbus-AC-A330-20140101.pdf

Airbus SAS. 2015a. Airbus A340-500 / -600 aircraft characteristics airport and maintenance planning. Issue Apr 01/01. Rev Oct 01/15 [online], [cited 5 February 2016]. Available from Internet: http://www.airbus.com/fileadmin/media_gallery/files/tech_data/AC/Airbus-ACA340-500-600-20140101.pdf

Airbus SAS. 2015b. Airbus A350-900 aircraft characteristics airport and maintenance planning. Issue Jun 01/13. Rev
Apr 01/15 [online], [cited 5 February 2016]. Available from Internet: http://www.airbus.com/fileadmin/media_gallery/ files/tech_data/AC/Airbus-AC-A350-Apr15.pdf

Airbus SAS. 2015c. Airbus A380 aircraft characteristics airport and maintenance planning. Issue Mar 30/05. Rev Dec 01/15 [online], [cited 5 February 2016]. Available from Internet: http://www.airbus.com/fileadmin/media_gallery/files/ tech_data/AC/Airbus-AC-A380-Dec2014.pdf

Airservices Australia. 2013. Australian organised track structure - AUSOTS [online], [cited 20 March 2016]. Available from Internet: https://www.airservicesaustralia.com/ausots/whatisaflextrack.asp

Asselin, M. 1997. An introduction to aircraft performance. Reston, VA: American Institute of Aeronautics and Astronautics. https://doi.org/10.2514/4.861529

Auckland International Airport. 2013. Auckland Airport fast facts [online], [cited 15 March 2016]. Available from Internet: https://www.aucklandairport.co.nz/ /media/Files/ Corporate/Fast\%20Facts\%202013.pdf

Baxter, G.; Kourousis, K. 2015. Temperature controlled aircraft unit load devices: the technological response to growing global air cargo cool chain requirements, Journal of Technology Management \& Innovation 10(1): 157-172. https://doi.org/10.4067/S0718-27242015000100012

Belobaba, P. P. 2016. The airline planning process, in P. Belobaba, A. Odoni, C. Barnhart (Eds.). The global airline industry. $2^{\text {nd }}$ ed. Chichester, UK: John Wiley \& Sons, 159-188.

Billings, J. S.; Diener, A. G.; Yuen, B. B. 2003. Cargo revenue optimization, Journal of Revenue and Pricing Management 2(1): 69-79. https://doi.org/10.1057/palgrave.rpm.5170050

Boeing B747SP Website. 2016. Boeing B747SP information and history [online], [cited 19 March 2016]. Available from Internet: http://www.747sp.com/

Boeing Commercial Airplanes. 2009. 777-200LR/-300ER/Freighter airplane characteristics for airport planning. Document D6-58329-2, Rev E [online], [cited 5 February 2016]. Available from Internet: http://www.boeing.com/assets/ pdf/commercial/airports/acaps/777_2lr3er.pdf

Boeing Commercial Airplanes. 2011. Boeing 747-400 Aircraft characteristics for airport planning, Document Number D6-58326-1, Rev D [online], [cited 5 February 2016]. Available from Internet: http://www.boeing.com/assets/ pdf/commercial/airports/acaps/747_4.pdf

Boeing Commercial Airplanes. 2012. Boeing 747-8 Airplane characteristics for airport planning, Document D6 58326-3, Rev B [online], [cited 5 February 2016]. Available from Internet: http://www.boeing.com/assets/pdf/commercial/airports/acaps/747_8.pdf

Boeing Commercial Airplanes. 2014. Boeing-Emirates-Finalize-Order-for-150-777Xs: World's largest 777 operator builds on airplane's success Record-breaking order includes combination of 777-8X, 777-9X [online], [cited 12 March 2016]. Available from Internet: http://boeing.mediaroom. com/2014-07-09-Boeing-Emirates-Finalize-Order-for150-777Xs

Boeing Commercial Airplanes. 2015. Boeing 787 aircraft characteristics for airport planning. Document Number D658333, Rev L [online], [cited 20 February 2016]. Available from Internet: http://www.boeing.com/assets/pdf/commercial/airports/acaps/787.pdf

Bradley, G. 2016. Grant Bradley: Emirates' non-stop flight to Dubai is a game changer. New Zealand Herald, January 29 [online], [cited 17 March 2016]. Available from Internet: http://www.nzherald.co.nz/business/news/article.cfm?c_ id=3\&objectid $=11581761$ 
Civil Aviation Authority, Qatar. 2016. Qatar Airways heading to Auckland, Bloomberg reports [online], [cited $16 \mathrm{March}$ 2016]. Available from Internet: http://www.caa.gov.qa/content/qatar-airways-heading-auckland-bloomberg-reports

Dawes Farquhar, J. 2012. Case study research for business. London: SAGE Publications. https://doi.org/10.4135/9781446287910

Dempsey, P. S.; Gesell, L. E. 1997. Air transportation: foundations for the $21^{\text {st }}$ century. Chandler, AZ: Coast Aire Publications.

Department of Infrastructure and Regional Development. 2014. The bilateral system - how international air services work [online], [cited 16 March 2016]. Available from Internet: https://infrastructure.gov.au/aviation/international/ bilateral_system.aspx

Ehmer, H.; Berster, P.; Bischoff, G. et al. 2008. Analyses of the European air transport market - airline business models. Report 1.01 [online], [cited 16 August 2016]. Available from Internet: http://ec.europa.eu/transport/modes/air/doc/ abm_report_2008.pdf

El Gazzar, S. 2016. Emirates again postpones world's longest flight from Dubai to Panama. The National, March 3 [online], [cited 11 August 2016]. Available from Internet: http:// www.thenational.ae/business/aviation/emirates-again-postpones-worlds-longest-flight-from-dubai-to-panama

Emirates Airline. 2016. Emirates goes non-stop Dubai-Auckland from March [online], [cited 15 February 2016]. Available from Internet: http://www.emirates.com/media-centre/ emirates-goes-non-stop-dubai-auckland-from-march

Etihad Airways. 2016. Our partner airlines [online], [cited 11 August 2016]. Available from Internet: http://www.etihad. com/en-us/about-us/our-partners/

Flight International. 2015. World Airliner Census 2015. Flightglobal Insight [online], [cited 22 March 2016]. Available from Internet: https://d1fmezig7cekam.cloudfront.net/ VPP/Global/Flight/Airline\%20Business/AB\%20home/Edit/ WorldAirlinerCensus2015.pdf

Flynn, D. 2015. First Boeing 777X tipped for 2018 [online], [cited 22 March 2016]. Available from Internet: http:// www.ausbt.com.au/first-boeing-777x-tipped-for-2018

Great Circle Mapper. 2016. Doha to Auckland Map [online], [cited 28 March 2016]. Available from Internet: http:// www.gcmap.com/mapui? $\mathrm{P}=$ doh,akl

Hamad International Airport. 2014. Hamad International Airport [online], [cited 17 March 2016]. Available from Internet: https://www.qatarairways.com/iwov-resources/tempdocs/press-kit/Hamad\%20International\%20Airport\%20 -\%20English.pdf

Hanlon, J. P. 2007. Global airlines: competition in a transnational industry. $3^{\text {rd }}$ ed. Oxford: Butterworth-Heineman.

Holloway, S. 2008. Straight and level: practical airline economics. $3^{\text {rd }}$ ed. Aldershot: Ashgate Publishing.

Horonjeff, F. R.; McKelvey, F. X.; Sproule, W. J. et al. 2010. Planning and design of airports. $5^{\text {th }}$ ed. New York: McGraw-Hill.

International Air Transport Association. 2015. Air cargo ends 2014 on a positive note. Press Release No. 3 [online], [cited 5 April 2015]. Available from Internet: http://www.iata.org/ pressroom/pr/Pages/2015-02-04-01.aspx

International Civil Aviation Organization. 2015. Annual report of the council: 2014 [online], [cited 15 March 2016]. Available from Internet: http://www.icao.int/annual-report-2014/Documents/Appendix_1_en.pdf

Kleymann, B.; Seristö, H. 2004. Managing strategic airline alliances. Aldershot, UK: Ashgate Publishing.
Kovessy, P. 2015. Qatar Airways adds to Boeing 777X order with $\$ 4.8$ billion purchase. Doha News, June 16 [online], [cited 19 March 2016]. Available from Internet: http://dohanews. co/qatar-airways-adds-to-boeing-777x-order-with-4-8-billion-purchase/

Kovessy, P. 2016. Qatar Airways expands in Eastern Europe, eyes flights to Chile and New Zealand. Doha News, January 25 [online], [cited 19 March 2016]. Available from Internet: http://dohanews.co/qatar-airways-expands-in-easterneurope-eyes-flights-to-chile-new-zealand/

Lecompte-Boinet, G. 2015. Airbus launches A350-900 ULR, Singapore signs for six [online], [cited 22 March 2016]. Available from Internet: http://www.ainonline.com/aviation-news/aerospace/2015-11-04/airbus-launches-a350900-ulr-singapore-signs-six

Leeham News and Comment. 2013. Ultra long range airplane market will limit 777-8 sales [online], [cited 18 March 2016]. Available from Internet: https://leehamnews. com/2013/10/03/ultra-long-range-airplane-market-willlimit-777-8-sales/

Milde, M. 2008. International air law and ICAO. Utrecht, The Netherlands: Eleven International Publishing.

Morrell, P. 2011. Moving boxes by air: the economics of international cargo. Farnham: Ashgate Publishing.

Morrison, S. A. 2007. Airline service: the evolution of competition since de-regulation, in V. J. Tremblay, C. H. Tremblay (Eds.). Industry and firm studies. Abingdon, UK: Routledge, 3-29.

Nordisk Aviation Products. 2016. Nordisk AKE (LD3) [online], [cited 17 March 2016]. Available from Internet: http://www. nordisk-aviation.com/en/ld-containers/nordisk-lite-family/nordisk-ake/

oneworld. 2016. Oneworld at a glance [online], [cited $11 \mathrm{Au}-$ gust 2016). Available from Internet: https://www.oneworld. com/news-information/oneworld-fact-sheets/oneworld-ata-glance

Oum, T. H.; Yu, C. 1998. Winning airlines: productivity and cost competitiveness of the world's major airlines, in Transportation, Research, Economics and Policy, Vol. 6. Norwell, MA: Kluwer Academic Publishers. https://doi.org/10.1007/978-1-4615-5481-3

Qatar Airways Cargo. 2016. Network ULD [online], [cited 18 August 2016]. Available from Internet: http://qrcargo.com/ networkuld

Qatar Airways. 2016a. Qatar Airways announces significant network expansion: 14 new global destinations [online], [cited 16 March 2016]. Available from Internet: http://www.qatarairways.com/global/en/press-release.page?pr_id=pressrelease_itbpressconf

Qatar Airways. 2016b. Our fleet [online], [cited 22 March 2016]. Available from Internet: http://www.qatarairways. com/au/en/our-fleet.page

Rahim, A. R.; Baksh, M. S. 2003. Case study method for new product development in engineer-to-order organisations, Work Study 52(1): 25-36. https://doi.org/10.1108/00438020310458705

Schmitt, D.; Gollnick, V. 2016. Air transport system. Vienna: Springer Verlag.

https://doi.org/10.1007/978-3-7091-1880-1

Singapore Airlines. 2015. SIA to re-start non-stop Singapore-US Flights with new A350 variant [online], [cited 12 August 2016]. Available from Internet: https://www.singaporeair. com/en_UK/us/media-centre/press-release/article/?q=en_ UK/2015/October-December/13Oct2015-1759 
Thomas, G. 2011. FAA extends 777 ETOPS approval to 330-minutes. ATWonline, December 14 [online], [cited 11 August 2016]. Available from Internet: http://atwonline. com/aircraft-engines-components/news/faa-extends-777etops-approval-330-min-1213

Torenbeek, E. 1976. Synthesis of subsonic airplane design. Delft, The Netherlands: Delft University Press.

United Airlines. 2016. UA 1: San Francisco - Singapore takes flight [online], [cited 11 August 2016]. Available from Internet: http://newsroom.united.com/2016-06-01-UA-1San-Francisco-Singapore-Takes-Flight

Yan, S.; Chen, C. H. 2008. Optimal flight scheduled models for cargo airlines under alliances, Journal of Scheduling, 11(3): 175-186. https://doi.org/10.1007/s10951-007-0020-1

Yin, R. K. 2009. Case study research: design and methods. $4^{\text {th }}$ ed. SAGE Publications: Thousand Oaks, CA.

Yin, R. K. 2014. Case study research: design and methods. $5^{\text {th }}$ ed. SAGE Publications: Thousand Oaks, CA: SAGE Publications.

Wikipedia. 2016. Singapore Airlines Flight 21 [online], [cited 20 September 2016]. Available from Internet: https://en.wikipedia.org/wiki/Singapore_Airlines_Flight_21

\section{Appendix}

\section{Definitions (taken from Boeing Commercial Airplanes 2009)}

Operating Empty Weight (OEW): Weight of structure, powerplant, furnishing systems, unusable fuel and other unusable propulsion agents, and other items of equipment that are considered an integral part of a particular airplane configuration. Also included are certain standard items, personnel, equipment, and supplies necessary for full operations, excluding usable fuel and payload. The OEW will vary airline by airline.

Maximum Design Zero Fuel Weight (MZFW): Maximum weight allowed before usable fuel and other specified usable agents must be loaded in defined sections of the aircraft as limited by strength and airworthiness requirements.

Maximum Design Takeoff Weight (MTOW): Maximum weight for takeoff as limited by aircraft strength and airworthiness requirements. (This is the maximum weight at the start of the takeoff run.)

Aircraft gross weight (all-up weight (AUW)): This is the total aircraft weight at any moment during the flight or ground operation. An aircraft's gross weight will decrease during a flight due to fuel consumption. 